\title{
A STUDY ON LISTENING PROBLEMS FACED BY STUDENTS OF HIGHER EDUCATION
}

\author{
1Fergina Lengkoan, ${ }^{2}$ Fivy Andries, ${ }^{3}$ Devilito P. Tatipang \\ 1,2,3Universitas Negeri Makassar, Indonesia \\ E-mail: ferginalengkoan@unima.ac.id
}

\begin{abstract}
The purpose of this study is to describe listening comprehension problems faced by students when taking the TOEFL-like test. This research is a descriptive research. This research is also categorized as a survey, the broad area of survey research encompasses any measurement procedures that involves asking questions of respondents. Furthermore, the researcher gave questions to the sample in form of questionnaire to get the data about listening problem faced by students taking TOEFL-like. In this research, the researcher used the questionnaire to collect the data. After discussion in the previous chapter, finally leads the researcher to make conclusion from what have been already discussed. The conclusion is among the twenty indicators, all the indicators came from various sides, such as: students' side, TOEFL organizer, material, listening equipment and another supported thing that related to the activity on TOEFL test especially listening skills.
\end{abstract}

Keywords: Listening, Problem: Students, TOEFL

\section{INTRODUCTION}

In learning English there are four language skills to be acquired: listening, speaking, writing, and reading. Each individual has different levels of difficulty, including difficulty in communicating, difficulty understanding Grammar, or minimal vocabulary. Basically everyone is experiencing the same thing when learning English, ranging from memorizing vocabulary, understanding grammar and other language structures. The above problems are not due to the learner's mistakes, but they may be errors in learning methods that are neither attractive nor too rigid, so an effective learning activity is required. In learning English students must be able to master the four aspects of skill (Lumentut, Y., \& Lengkoan, 2021). In the skill aspect students learn about how to pronounce or pronounce words correctly, write sentences correctly according to grammar and listen to foreign sentences correctly and thoroughly so that what is heard corresponds to what is spoken.

One aspect of the skills that is difficult to learn by students is listening. Many factors contribute to make listening in English difficult to acquire. the most common answers were poor classroom conditions, not having visual aids, unfamiliar vocabulary, unclear pronunciation, speech rate, boring topics being exposed to longer texts (Hasan, 2000), and phonological features (Chiang \& Dunkel, 1992). These problems make listening difficult so that students often feel lazy and scared when they follow English lessons. In addition to the above problems, Indonesian learners of English rarely listen to English spoken by native speakers. Unfamiliarity with native speakers pronunciation of English makes it more difficult for students when they are to listen to texts spoken by native speakers of English. This unfamiliarity with native speakers' pronunciation may affect our listening ability. So, Lack of exposure to the language results in comprehension problem (Lalogiroth \& Tatipang, 2020). TOEFL test is a proficiency test. According to Brown (2007), "TOEFL is a test of English proficiency - generally includes four skills speaking, listening reading, writing) used by a lot of educational institutions as an indicator of students' proficiency". The main goal of TOEFL is not to test the use of daily English but to capture test takers' ability to function in an academic context which principally has its own genre, different from the daily language use (Zareva,2005). Therefore, items in the test represent various kinds of topics, some of which are unfamiliar to the test takers.

Consequently, it is difficult for test-takers to reach the minimal passing grade. Research on listening problems faced by TOEFL takers have been revealed by a number of researchers. Darti and Asmawati (2017), for example focused her study on three factors: (1) listening 
material, (2) listener factor, and (3) physical setting. She found out that accents/pronunciation, speed of speech, insufficient vocabulary, different accent of the speakers, lack of concentration, and bad quality of recording were the major problems encountered by students at English Education Department. Silviyanti et al., (2017) revealed that among 17 sub skills, "Listen for double negative expression" was the most difficult questions for the students to answer, followed by "listen to English Idioms", and "lisien for synonyms". Antoni (2014) found that the problems faced are that they get difficulties to understand the spoken language because the speaker speaks toofast and the hard materials are the reason given.

In connection with TOEFL test, English Department at Manado State University requires its students to take a TOEFL-like test as a requirement to sit in their comprehensive examination. The test takers have to reach minimally 475 points. Although the passing grade is low for students majoring in English, still this minimal passing grade is difficult to reach. In a number of interviews with the students taking the test it was revealed that listening section was the most difficult of all for them. Since the interviews involved only 9 test-takers, it is necessary to uncover listening problems faced by TOEFL-like test takers.

\section{THEORETICAL FRAMEWORK}

Darti and Asmawati (2017) revealed that accents, pronunciation, speed of speech, insufficient vocabulary, different accent of the speakers, lack of concentration, and bad quality of recording were the major problem faced by TOEFL takers. Based on their finding, the researcher finds it necessary to address these research problems:

(1) Do students of English education Department at UNIMA also faced listening problems as revealed by Darti and Asmawati (2017)?

(2) Which of the above-mentioned problems is the most difficult for them?

The purpose of this study is to describe listening comprehension problems faced by students when taking the TOEFL-like test administered by English Department Program at Manado State University in 2019.

\section{The Significance of the Study}

This study provides information about listening problems faced by students when taking TOEFL-like test. Information provided is important for English teachers, test administrators, and researchers in listening in English. The information helps English teachers know listening problems commonly faced by students in listening. This knowledge helps them take necessary actions to help their students overcome the existing problems Knowledge of problems commonly faced by students or test takers help test administrators by take necessary actions to minimize effects of test on students test performance. Researchers in listening may conduct similar studies involving different subjects. They may also conduct follow up studies to find ways (strategies) to overcome listening problems and at the same tome increase students listening ability.

\section{Delimitation of the Scope}

The study is delimited to English education students at Manado State University who take TOEFL-like test administered by the English education department of the university in February-March period 2019.

\section{Operational Definition of Key Terms used}

Listening refers to grasping of what is said or heard. Listening ability refers to one's ability to accurately write down recorded texts read by native and non-native speakers of English. TOEFL is a standardized test to measure the English language ability of non-native speakers wishing to enrol in English-speaking universities. TOEFL-like refers to test which is similar as TOEFL in terms of format, content, often used for TOEFL preparation.

\section{RESEARCH METHOD Research Design}


Globish (An English-Indonesian journal for English, Education and Culture)

Vol. 11, No.1, January 2022,

P-ISSN: 2301-9913, E-ISSN: 2597-9132

DOI: http://dx.doi.org/10.31000/globish.v7i2

This research is descriptive research. According to Gay (1981:12), Descriptive research involves collecting data in order to test hypothesis or to answer question concerning the current status of the subject of the study". This research is also categorized as a survey, the broad area of survey research encompasses any measurement procedures that involves asking questions of respondents. Furthermore, the researcher will give questions to the sample in form of questionnaire to get the data about listening problem faced by students taking TOEFLlike administered by English Education department.

Population and Sample

According to Gay (1981:86), "Population is a group of interest to the researcher, the group to which she or he would like the result of the study generalized". The sample in this research will be the students of English education department taking the test during FebruaryMarch period 2019. All those taking the test during this period will be the sample of this study. Research Instrument

In this research, the researcher used the questionnaire to collect data. The questionnaire was developed based on listening problems revealed by Darti and Asmawati (2017). Having developed it, the questionnaire was validated using expert judgment technique. The purpose was to determine whether good in terms of its construct and its contents. For this purpose, a panel expert involved scored the questionnaire based on this scoring category. Result of their validation is presented in Table 3A.

Tabel 3B. Construct \& Content Validity Criteria

\begin{tabular}{|l|l|}
\hline Presentasi Validasi & Kriteria \\
\hline $81 \%-100 \%$ & Very high \\
\hline $61 \%-80 \%$ & High \\
\hline $41 \%-60 \%$ & High enough \\
\hline $21 \%-40 \%$ & Low \\
\hline $0 \%-20 \%$ & Very low \\
\hline
\end{tabular}

Based on the questionnaire, scoring category and validity criteria, the panel came up with their judgement as presented in Table 3C.

Table 3C. Construct \& content Validity Scoring

\begin{tabular}{|c|c|c|}
\hline Validator & Score & $\mathbf{\%}$ \\
\hline Validator 1 & 4 & $80 \%$ \\
\hline Validator 2 & 3 & $60 \%$ \\
\hline Total & & $70 \%$ \\
\hline
\end{tabular}

Having validated it, a field try out was conducted in order to verify whether it was empirically valid and reliable. ltem validity was analyzed statistically using point biserial correlation. This statistics is usually used to analyze validity of discreet data such as data obtained using objective type test. In this study, the questionnaire used was the one which required respondents to give yes/no answer. That is why the statistic was used. Results of 
statistical analysis indicated that all the questionnaire items were valid as shown in Table 3D.

Table 3D. Validity coefficient of questionnaire items

\begin{tabular}{|c|c|c|c|c|c|c|c|c|c|c|c|c|c|c|c|}
\hline No & \multicolumn{10}{|c|}{ Questionnaire Items } & \\
& \multicolumn{10}{|c|}{} & \multicolumn{10}{|c|}{} \\
& 1 & 2 & 3 & 4 & 5 & 6 & 7 & 8 & 9 & 10 & 11 & 12 & 13 & 14 & 15 \\
\hline rpbis & .65 & .84 & .84 & .52 & .61 & .45 & .58 & .52 & .58 & .46 & .69 & .69 & .59 & .79 & .45 \\
\hline
\end{tabular}

In general, if correlation coefficient of an item is larger than 0.3 , the item is considered as valid (Weiresma and Jurs, 1990) Reliability of the questionnaire was determined using Kuder Richhardson 20 or KR-20. As with point biserial for item validity of objective type test, KR-20 is used to compute reliability of discreet data (data which are scored on 1 or 0 basis. The questionnaire was statistically analyzed using KR-20. The formula is:

$$
\mathrm{r}_{\mathrm{KR}-20}=\left(\frac{k}{k-1}\right)\left(1-\frac{\sum p q}{02}\right)
$$

Where:

$\mathrm{r}_{\mathrm{KR}-20}$ is the Kuder-Richardson formula 20

$\mathrm{k}$ is the total number of test items

$\sum$ indicates to sum

$\mathrm{p}$ is the proportion of the test takers who pass an item

$\mathrm{q}$ is the proportion of test takers who fail an item-

02 is the variation of the entire test

Based on the tryout data (scores), the following results were obtained:

Table 3E. Results of $\mathrm{X}, \mathrm{X}^{2}$, pq, $\mathrm{O}^{2}$ calculations

\begin{tabular}{|c|c|}
\hline$\sum X$ & 162 \\
\hline$\sum X^{2}$ & 1654 \\
\hline $\mathrm{n}(\mathrm{k})$ & 17 \\
\hline $\mathrm{Pq}$ & 3.44 \\
\hline $\mathrm{O}^{2}$ & 6.48 \\
\hline
\end{tabular}

Furthermore, based on the results shown in Table 3E, statistical analysis was run. The result indicated that reliability of coefficient of the questionnaire was 0.4982 (rKR-20 $=0.4982$ ). This coefficient indicated that the reliability of the questionnaire is good (Indra Iskandar, 2016). As pointed out before, Darti and Asmawati (2017) revealed that (1) pronunciation, (2) speed of speech, (3) insufficient vocabulary, (4) different accent of the speakers, (5) lack of concentration, 
Globish (An English-Indonesian journal for English, Education and Culture)

Vol. 11, No.1, January 2022,

P-ISSN: 2301-9913, E-ISSN: 2597-9132

DOI: http://dx.doi.org/10.31000/globish.v7i2

and (6) bad quality of recording were the major problem faced by TOEFL takers. Based on these aspects, the questionnaire was developed. The questionnaire referred to is shown in Table $3 \mathrm{~F}$.

Table 3F. Data Collecting Instrument

\begin{tabular}{|c|l|l|l|}
\hline No & Questionnaire ltems & Yes & No \\
\hline 1 & Difficulty due to lack of vocabularies knowledge & & \\
\hline 2 & Difficulty due to lack of grammatical knowledge & & \\
\hline 3 & Difficulty to predict what the speakers' is talking about & & \\
\hline 4 & Difficulty in guessing unknown words or phrase & & \\
\hline 5 & Difficulty in recognizing the main points & & \\
\hline 6 & Difficulty in understanding long utterances & & \\
\hline 7 & Difficulty in listening of speech speed & & \\
\hline 8 & Difficulty in understanding different accents & & \\
\hline 9 & Difficulty in understanding unfamiliar topic & & \\
\hline 10 & Difficulty in understanding of the contents & & \\
\hline 11 & Difficulty due to lack of self confidence & & \\
\hline 12 & Difficulty due to lack of concentration & & \\
\hline 13 & Feeling depressed when find difficulty & & \\
\hline 14 & Difficulty due to environmental conditions & & \\
\hline 15 & Difficulty due to unclear recording & & \\
\hline
\end{tabular}

Where:

A = Always

$\mathrm{B}=$ Often

$\mathrm{C}=$ Sometimes

$\mathrm{D}=$ Never

This present study tries to find out which of the existing problems 1S the most/least difficult for the TOEFL takers. For this purpose, the respondents were to rank the factors from the most difficult one (1) to the least difficult (5).

Table 3G. Questionnaire 2.

\begin{tabular}{|lll|l|}
\hline $\begin{array}{l}\text { Kesulitan } \\
\text { Listening }\end{array}$ & utama pada bagian & Urutan sesuai tingkat kesulitan \\
\hline
\end{tabular}




\begin{tabular}{|l|l|}
\hline Speed of speech & \\
\hline $\begin{array}{l}\text { Different accent/pronunciation of the } \\
\text { speakers }\end{array}$ & \\
\hline Lack of concentration & \\
\hline Insufficient vocabulary & \\
\hline Bad quality of recording & \\
\hline
\end{tabular}

\section{Data Analysis}

The data already identified and classified were analyzed quantitatively using the formula below:

$$
\%=\frac{\text { Number of each type of errors }}{\text { Total number of listening problems }} \times 100 \%
$$

\section{RESULTS AND DISCUSSION Data Display}

In order to identify and describe students' perceptions of what listening problems are faced by TOEFL-like test participants administered by English Education Department at Manado State University, data obtained through the primary data of the questionnaire as a research instrument. In this research, a yes/no questionnaire with s 15 items and an item asking the respondents to choose and order the problems they faced based on the level of difficulty. The yes/no questionnaire was used to collect data to answer the first research question, and the second was used to answer the second research question. The data collected from the respondents were presented in Table $4 \mathrm{~A}$ and $4 \mathrm{~B}$ respectively.

Table 4A. Data from Yes/No questionnaire

\begin{tabular}{|c|l|c|c|c|}
\hline No & Questionnaire Items & Yes & No & Total \\
\hline 1 & $\begin{array}{l}\text { Anda mengalami kesulitan karena penguasaan kosa-kata yang } \\
\text { tidak memadai. }\end{array}$ & $\begin{array}{l}\text { Anda mengalami kesulitan karena pengetahuan grammar yang } \\
\text { kurang memadai. }\end{array}$ & & \\
\hline 3 & Anda kesulitan memprediksi apa yang akan dikatakan pembicara. & & \\
\hline 4 & Anda kesulitan menebak makna kata /phrase yang anda dengar. & & & \\
\hline 5 & $\begin{array}{l}\text { Anda kesulitan mengidentifikasi ide pokok dari teks yang } \\
\text { diperdengarkan. }\end{array}$ & & \\
\hline 6 & Anda kesulitan memahami ujaran pembicara yang panjang & & & \\
\hline 7 & Anda kesulitan mengikuti pembicara yang berbicara cepat & & \\
\hline
\end{tabular}


Globish (An English-Indonesian journal for English, Education and Culture)

Vol. 11, No.1, January 2022,

P-ISSN: 2301-9913, E-ISSN: 2597-9132

DOI: http://dx.doi.org/10.31000/globish.v7i2

\begin{tabular}{|c|l|l|l|l|}
\hline 8 & Anda kesulitan dengan aksen/ucapan pembicara & & \\
\hline 9 & Anda kesulitan memahami teks yang topiknya asing bagi anda & & \\
\hline 10 & Anda kesulitan memahami apa yang dibicarakan (yang didengar) & & \\
\hline 11 & Anda kesulitan mengerjakan tes karena kurang percaya diri & & \\
\hline 12 & $\begin{array}{l}\text { Anda kesulitan karena tidak biasa berkonsentrasi mendengar apa } \\
\text { diperdengarkan. }\end{array}$ & $\begin{array}{l}\text { Anda kesulitan memahami apa yang diperdengarkan karena } \\
\text { merasa } \\
\text { tertekan }\end{array}$ & & \\
\hline 14 & $\begin{array}{l}\text { Kesulitan karena lingkungan test yang bísing } \\
15\end{array}$ & Kesulitan karena qualitas rekaman yang tidak baik & & \\
\hline
\end{tabular}

Data concerning level of difficulty of factors which often hinder their listening comprehension. The respondents were to order the following five factors from the most difficult one (1) to the least difficult one (5). The result are presented in table 4B.

Table 4B Factors hinder listening seen in terms of difficulty level

\section{Listening Factors}

Speech Speed

Accent/Pronunciation

Vocabulary

Lack of Concentration

Quality of Recording

\section{Frequency}

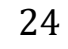

23

22

21

28

\section{Data Analysis}

It has been pointed out before that the data already collected in this study were analyzed quantitatively in percentage form. The following is the analysis of each of the items in the questionnaire.

Item no 1, anda mengalamai kesulitan karena penguasaan kosa-kata yang tidak memadai. The responses to the items are as follows: of 32 respondents, 22 or $69 \%$ respondents considered vocabulary or their lack of vocabulary was the reason for their difficulty in listening. The rest, 10 or $31 \%$ respondents had no problem with vocabulary in listening section.

Item no 2, anda mengalami kesulitan karena pengetahuan grammar yang tidak memadai. This item, 17 or $53 \%$ the respondents' responses considered lack of grammar knowledge a problem, whereas 15 or $47 \%$ respondents had no problem with grammar in listening section.

Item no 3, anda kesulitan memprediksi apa yang akan dikatakan pembicara. Of 32 respondents, 24 or $75 \%$ respondents found it difficult to predict what the speakers was talking about. The rest, 8 or $25 \%$ respondents did not find it to predict what the speaker said. 
Item no 4, anda kesulitan menebak makna kata /phrase yang anda dengar Of the total 32 respondents, 18 or $56 \%$ respondents found it difficult to guess the meaning of words/phrases in the texts they heard. The rest, 14 respondents or $46 \%$ had not problem with guessing the meanings of the words/phrases in the texts/conversations they heard.

Item no 5, anda kesulitan mengidentifikasi ide pokok dari teks yang diperdengarkan. The respondents responses to this item were as follows: 23 or $72 \%$ respondents considered main idea identification a problem for them. The rest, 9 or $28 \%$ respondents had no problem with main idea identification. Item no 6 , anda kesulitan memahami ujaran pembicara yang parnjang. Concerning this item, 25 or $78 \%$ respondents found it difficult to understand long utterances they heard. Only 7 or $22 \% \%$ did not have problem with long utterances they heard. Item no 7 , anda kesulitan mengikuti pembicara yang berbicara cepat. Of all the respondents, 29 or $91 \%$ respondents found that they had difficulty with the speech speed. The rest, 3 or $9 \%$ did not consider it a problem in listening.

Item no 8, anda kesulitan dengan aksen pembicara. The respondents gave these responses: 28 or $88 \%$ found it difficult to understand what the speaker said due to unfamiliar accent. The rest said no to this item, meaning that they found no problem with speaker's acco

Item no 9, anda kesulitan memahami teks yang topiknya asing bagi anda. When asked whether comprehension problem they faced was due to unfamiliar topic of the texts they heard, 23 or $72 \%$ of the respondents admitted that $\mathrm{u}$ faced problem in comprehending texts with unfamiliar topics. The rest, 9 or 200 respondents had no problem comprehending texts with unfamiliar topies.

Item no 10, anda kesulitan memahami apa yang dibicarakan ang didengar). Of the total 32 respondents, 26 or $81 \%$ of them found it difficult to comprehend contents of the texts they heard. Only 6 or 19\% respondents had no comprehension problem with texts contents.

Item no. 11, anda kesulitan karena kurang percaya diri. When asked whether they had problems doing the test because of their lack of self-confidence, 22 or 69 respondents said that they did, and 10 or $31 \%$ said they didn't.

Item no 12, anda kesulitan karena tidak biasa berkonsentrasi mendengar apa yang diperdengarkan. When asked whether they could fully concentrate to listen to what they heard, 25 or $78 \%$ respondents found it difficult to concentrate to what they heard. Only 7 or $22 \%$ could fully concentrate on what they heard.

Item no 13, anda kesulitan memahami apa yang diperdengarkan karena merasa tertekan (misalnya, karena cepatnya pembicaraan, tidak terbiasa dengan ucapan peutur asli). 26 or 81\% respondents were under-pressured during the listening test; Only 6 or $19 \%$ were at ease during the test.

Item 14, anda mengalami kesulitan memahami apa yang no diperdengarkan karena lingkungan test yang bising. Of the total sample, 8 or $25 \%$ respondents said yes, whereas the majority of them 24 or $75 \%$ said no. meaning that test environment did not have any effect of their comprehension.

Item no 15, kesulitan karena qualitas rekaman yang tidak baik. When asked about the quality of recording used, 7 or $227 \%$ considered the quality of recording a problem in the listening test. Majority of them, 25 or 78\% respondents, had no problem with the recording used.

The data analysis indicates that all the respondents faced the same listening problems as revealed by Darti and Asmawati (2017). Some of the problems such as speech speed, speaker's accent, comprehension, feeling depressed, prediction incoming information, lack of concentration, lack of self-confidence were faced by majority of the respondents are serious; only a few respondents faced difficulties in factors such as environmental condition and quality of recording used.

When asked to put the factors which often hindered their listening comprehension in accordance with their levels of difficulty, the respondents gave the following responses

The discussion will always connect to the introduction by way of the research questions or hypotheses you posed and the literature you reviewed, but it does not simply repeat or 
Globish (An English-Indonesian journal for English, Education and Culture)

Vol. 11, No.1, January 2022,

P-ISSN: 2301-9913, E-ISSN: 2597-9132

DOI: http://dx.doi.org/10.31000/globish.v7i2

rearrange the introduction; the discussion should always explain how your study has moved the reader's understanding of the research problem forward from where you left them at the end of the introduction.

To make your message clear, the discussion should be kept as short as possible while clearly and fully stating, supporting, explaining, and defending your answers and discussing other important and directly relevant issues. Care must be taken to provide a commentary and not a reiteration of the results. Side issues should not be included, as these tend to obscure the message.

Table 4C. Listening Factors seen in terms of level Difficulty

\begin{tabular}{|l|l|l|}
\hline Listening Factors & Frequency & Percentage \\
\hline Speech Speed & 24 & $75 \%$ \\
\hline Accent/Pronunciation & 23 & $72 \%$ \\
\hline Vocabulary & 22 & $69 \%$ \\
\hline Lack of Concentration & 21 & $66 \%$ \\
\hline Quality of Recording & 28 & $88 \%$ \\
\hline
\end{tabular}

The data in Table 4B indicate that speed of speech is the most difficult problem faced by the respondents. 23 or $72 \%$ respondents put speaker's accent and pronunciation which are unfamiliar to the respondents is in the second position. The third position 1s lack of vocabulary which is considered difficult by 22 or $69 \%$ respondents. Lack of concentration which is due to speed speech, unfamiliar pronunciation, and lack o vocabulary is in the fourth position with 21 or 66 respondents. Furthermore, 28 or $88 Y \%$ Or majority of the respondents have no problem with the quality of recording used.

\section{Discussions}

The data already analyzed indicate that the respondents faced similar problems as those faced by the respondents involved in Darti and Asmawati's study (2017) In the present study the questionnaire used deals with five factors which strongly affect listeners' comprehension: (1) language knowledge, (2) speaker, (3) text, (4) listener, and (5) environmental/equipment. Concerning language knowledge (item $1,2 \& 3$ ), the respondents found it difficult to comprehend what they heard because they were in lack of vocabulary, grammar knowledge and meanings of words/phrases. Speech speed, speaker's

Majority of the respondents found accent/pronunciation, and length of speaker utterances the most difficult ones. Text factor such as unfamiliar text topics, main idea identification also contributes to respondents listening comprehension problems. In addition to the above mentioned problems, listening comprehension problems also come from TOEFL testtakers. The present study revealed that TOEFL test-takers find it difficult to focus their attention on what is being said, feel depressed and lose their self-confidence during the test. Most of the respondents faced no problem with quality of recoding and test environment.

\section{CONCLUSION}


After discussion in the previous chapter, finally leads the writer to make conclusion from what have been already discussed so far. The conclusion 1s among the twenty indicators, all the indicators came from various sides, such as students side, TOEFL organizer, material, listening equipment and another supported things that related to activity on TOEFL test especially Listening skills. However, most of students found difficulties in listening by themselves, it means that students need to improve their ability in listening through several things like listening music, watching youtube videos, listening podcast and etc. Therefore, from daily activities like that, they will show an improvement in order to support their ability in TOEFL test success and get a higher score than before. In this study, showed that students were need to reflect their weaknesses in English listening, so they can understand and find their own solution to use an appropriate way/technique for that case.

\section{REFERENCES}

Brown, H. D. 2002. Language Assessment: Principles and Classroom Practices. San Fransisco: San Fransisco State University Press.

Buck, 2003. Assessing Listening. Cambridge: Cambridge University Press.

Gilakjani, Abbas Pourhosein \& Sabouri, Narjes Banou. 2016. Leaiic Listening Comprehension Dificulties in English Language Learning A Literature Review. English Language Teaching: Vol. 9, No. 6; ISSN 19104742 E-ISSN 1916-4750

Hamouda, Arafat. 2013. An Investigation of Listening Comprehension Problems Encountered by Saudi Students in the EL Listening Classroom. International Journal of Acadenmic Research in Progressiv Education and Development, Vol. 2, No. 2. ISSN: 2226-6348

Hornby, A. S. 1995. Oxford Advanced Learner's Dictionary. New York: Oxford University Press.

Lado, R. 1964. Language Testing. London: Longman Group Ltd.

Lalogiroth, A., \& Tatipang, D. P. (2020). An Analysis Of English National Exam And English Teachers'perception Using Bloom's Revised Taxonomy. Journal of English Culture, Language, Literature and Education, 8(1), 1-21.

Lumentut, Y., \& Lengkoan, F. (2021). The Relationships of Psycholinguistics in Acquisition and Language Learning. Journal of English Culture, Language, Literature and Education, 9(1), 17-26.

Lynch, T. 998. Theoretical Perspective on Listening. Annual Review of Applied Linguistics, 18, 3 19.

Moore, Gary W. 1983. Developing and Evaluating Educational Research. Boston: Little, Brown \& Company.

Oller, J.W 1979. Language Test at School. London: Longman

Rost, M. 1991. Listening Action Activities for Developing Listening in Language Teaching. London: Prentice Hall.

Suriyatham, Watjana. 2011. A Study of English Listening Problems and Listening Proficiency of Business Students at Bangkok University Sradej appendices.pdf Anandapong.http://digi.library.tu.ac.th/thesis/lg/0641/title

Usti Desliana., Marzuki., \& Hadriana. 2016. A Study on Listening Comprehension Problems Faced by Second Year Students of English Study Program FKIP, Riau. English Study Program, Teacher Training and Education Faculty Universitas Riau. https://jom.unri.ac.id/index. php/JOMFKIP/article/viewFile/13565/1312 9

$\mathrm{Wu}$ Xiao Juan \& Mohamad Jafre Zainol Abidin. (2013). English Listening Comprehension Problems of Students from China Learning English in Malaysia. Language in India, Vol. 13; 4. www.languageinindia.com ISSN 1930-2940 